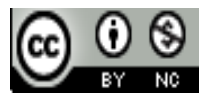

Jurnal Pendidikan Matematika Indonesia is licensed under A Creative Commons Attribution-Non Commercial 4.0 International License.

\title{
PENGEMBANGAN LKS BERBASIS DONGENG UNTUK MENINGKATKAN LITERASI MATEMATIS SISWA SEKOLAH DASAR SE-KOTA SINTANG
}

\author{
Olenggius Jiran Dores ${ }^{1)}$, Beni Setiawan ${ }^{2)}$ \\ ${ }^{1)}$ STKIP Persada Khatulistiwa, Sintang, Indonesia \\ E-mail: olenggius@gmail.com \\ ${ }^{2)}$ STKIP Persada Khatulistiwa, Sintang, Indonesia \\ E-mail: benisetiawan1892@gmail.com
}

\begin{abstract}
Abstrak. Penelitian ini bertujuan untuk meningkatkan Literasi matematis siswa kelas IV SD se kota Sintang, mengkaji Perbedaan literasi matematis siswa antara sebelum dan setelah mengerjakan lks berbasis dongeng dan mengembangkan lks berbasis dongeng untuk meningkatkan literasi matematis siswa kelas IV sekolah dasar se kota Sintang. Subjek dalam penelitian ini adalah 63 siswa kelas 4 dari 21 SD di Kota Sintang dengan kategori siswa berkemampuan tinggi, berkemampuan sedang dan berkemampuan rendah. Desain penelitian ini merupakan riset and development. Adapun tahapannya adalah (1). Studying research findings, (2). Developing the product, (3). Field testing, (4). Revising. Kesimpulan dari penelitian ini adalah; kemampuan literasi matematis siswa kelas IV SD se-kota Sintang masih rendah dengan nilai rata - rata 42,90 pada semua level kemampuan dengan persentase $80,32 \%$, terdapat perbedaan kemampuan literasi matematis sebelum dan setelah mengerjakan lks berbasis dongeng dengan kenaikan rata - rata hasil tes 8,48, lks berbasis dongeng dapat meningkatkan kemampuan literasi matematis siswa se-kota Sintang.
\end{abstract}

Kata Kunci: LKS Berbasis Dongeng, Literasi Matematis; Siswa SD; Kota Sintang

\section{PENDAHULUAN}

Progress in International Reading Literacy Study (PIRLS) merupakan studi internasional dalam bidang membaca pada anak-anak kelas empat sekolah dasar di seluruh dunia di bawah koordinasi The International Association for the Evaluation of Educational Achievement (IEA). Hasil pemetaan oleh Trends in International Mathematics and Science Study (TIMSS) dan Progress in International Reading Literacy Study (PIRLS) tahun 2015 pada Achievement in Mathematics Content Domains siswa, Indonesia berada pada posisi Low International Benchmark dengan Overall Mathematics Average Scale Score 397. Terjadi penurunan hasil jika dibandingkan dengan perolehan skor rata-rata tahun 2011 yakni 407

PIRLS melakukan studi terhadap kemampuan membaca anak-anak Sekolah Dasar kelas empat atau usia rata-rata siswa pada waktu mengikuti studi ini adalah 9,5 tahun. Skor prestasi membaca rata-rata siswa Indonesia pada tahun 1015 adalah 397, menduduki posisi ke enam dari urutan bawah, di atas Jordan (388), Saudi Arabia (383), Maroko (377), Afrika Selatan (376) dan Kuwait (353) (TIMMS \& PIRLS, 2015).

Di samping menggunakan rata-rata skor prestasi membaca $=500$ poin sebagai kriteria, PIRLS juga menggunakan kriteria lain untuk memetakan sejauhmana prestasi membaca negara peserta menurut benchmark internasional. Benchmark tersebut dikategorikan dalam 4 (empat) level kemampuan, yaitu (1) sangat tinggi (advanced international benchmark) dengan skor 625, (2) tinggi (high international benchmark) dengan skor 550, (3) sedang (intermediate international benchmark) dengan skor 475, dan (4) rendah (low international benchmark) dengan skor 400 (Tjalla,2010). 
Berdasarkan level kemampuan tersebut menunjukan bahwa siswa Indonesia mengalami masalah literasi. Hal ini disebabkan karena anak Indonesia tidak mampu dalam hal (1) mengidentifikasi, membedakan, dan menunjukkan detail peristiwa yang ada dalam bacaan, (2) menginterpretasi dan mengintegrasikan ide antar bacaan (3) mengenal dan menginterpretasikan bahasa-bahasa gambar dan pesan abstrak, (4) menguji dan mengevaluasi struktur cerita, dan (5) menjelaskan hubungan antara tindakan, peristiwa, perasaan dalam bacaan. Selanjutnya, $19 \%$ pada level sedang (intermediate), dan $54 \%$ pada level rendah (low), dan $25 \%$ lainnya berada di bawah level rendah (Tjalla, 2010).

Hal ini tentunya harus menjadi perhatian serius kita bersama, jika hal ini dibiarkan dan tanpa ada solusi maupun tindakan nyata yang dilakukan, maka siswa Indonesia akan selalu terpuruk dalam lubang hitam pendidikan. Kami selaku tim peneliti akan mencoba mengatasi masalah tersebut melalui solusi yang kami tawarkan.

Untuk mengatasi masalah literasi tersebut, kami tim peneliti akan mengembangkan Lembar Kerja Siswa (LKS) berbasis dongeng bermuatan matematis. Hal ini dikarenakan melalui dongeng pendidikan karakter dapat ditanamkan dan diperkuat pada peserta didik (Rosada, 2016) serta dapat meningkatkan minat membaca pada siswa Sekolah Dasar (SD) kelas IV (Pertiwi, 2011). Selain itu, dongeng juga dapat meningkatkan kemampuan berkomunikasi untuk pengembangan moral anak-anak usia 7-8 tahun (Ardini, 2012). Sedangkan LKS merupakan salah satu sumber belajar yang dapat dikembangkan oleh guru sebagai fasilitator dalam kegiatan pembelajaran. Oleh karenanya LKS menjadi sumber belajar dan media pembelajaran (Widjajanti, 2008)

Berdasarkan pemaparan diatas, kami tim peneliti merasa tertantang untuk mengatasi keterpurukan siswa Indonesia saat ini khususnya siswa kelas IV SD. Kami akan melakukan pengembangan LKS berbasis dongeng untuk meningkatkan literasi matematis siswa SD se kota sintang.

\section{METODE}

Jenis dan desain penelitian ini merupakan penelitian pengembangan atau Riset dan Development (R\&D). Melalui penelitian ini diharapkan dapat menjadi sarana menyambung penelitian yang lebih banyak menguji teori kearah menghasilkan produk-produk yang dapat digunakan langsung oleh pengguna. Desain penelitian mengikuti desain Borg dan Gall dengan tahapan sebagai berikut:

A. Studying research findings pertinent to the product to be developed

Melakukan studi pendahuluan tentang literasi matematis siswa untuk mencari temuan-temuan penelitian terkait dengan produk yang akan dikembangkan dalam hal ini adalah LKS Berbasis Dongeng.

B. Developing the product base on this findings

Mengembangkan produk berdasarkan temuan penelitian tersebut.

C. Field testing it in the setting where it will be used eventually

Dilakukannya uji lapangan dalam seting atau situasi senyatanya dimana produk tersebut nantinya digunakan.

D. Revising it to correct the deficiencies found in the field-testing stage

Melakukan revisi untuk memperbaiki kelemahankelemahan yang ditemukan dalam tahap-tahap uji lapangan.

Jenis data dalam penelitian ini bersifat kuantitatif dan kualitatif yang diperoleh dari hasil tes dan angket. Teknik yang digunakan adalah tes pengukuran, observasi tidak langsung dan wawancara. Instrumen yang digunakan berupa angket validasi ahli, soal tes literasi matematis, lks, angket dan pedoman wawancara siswa.

\section{HASIL DAN PEMBAHASAN}

\section{A. Hasil Penelitian}

Data diambil dari hasil tes siswa kelas IV yang berjumlah 63 siswa dari 21 SD yang peneliti tentukan yang terdapat di Kota Sintang. Data yang diperoleh dari penelitian ini disajikan dalam tabel berikut:

TABEL I

NILAI RATA - RATA HASIL TES AWAL LITERASI MATEMATIS SISWA

\begin{tabular}{clc}
\hline No. & Aspek yang diamati & Rata-rata nilai \\
\hline 1 & Pemecahan masalah & 43,1 \\
2 & Komunikasi matematis & 40,4 \\
3 & Penalaran matematis & 41,2 \\
4 & Koneksi matematis & 42,5 \\
5 & Representasi matematis & 47,3 \\
& Rata - rata & $\mathbf{4 2 , 9 0}$ \\
\hline
\end{tabular}

TABEL II

KRITERIA ANGKET VALIDASI AHLI MENGENAI LKS BERBASIS DONGENG

\begin{tabular}{cll}
\hline No. & Skor & Kriteria \\
\hline 1 & 100 & Valid tanpa revisi \\
2 & $81-99$ & Valid dengan revisi ringan \\
3 & $61-80$ & Valid dengan revisi sedang \\
4 & $<60$ & Tidak valid \\
\hline
\end{tabular}

(Husna, 2015) 


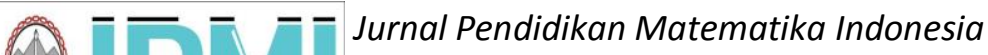 \\ Volum 3 Nomor 2 bulan September 2018 Page 62 - 65 \\ p-ISSN: 2477-5967 e-ISSN: 2477-8443}

TABEL III

HASIL ANALISIS KEMAMPUAN LITERASI MATEMATIS SISWA

\begin{tabular}{clc}
\hline No. & Aspek yang diamati & Rata-rata nilai \\
\hline 1 & Pemecahan masalah & 57,1 \\
2 & Komunikasi matematis & 50,2 \\
3 & Penalaran matematis & 48,8 \\
4 & Koneksi matematis & 51,5 \\
5 & Representasi matematis & 49,3 \\
& Rata - rata & $\mathbf{5 1 , 3 8}$ \\
\hline
\end{tabular}

TABEL IV

KRITERIA PENILAIAN ANGKET RESPON SISWA

\begin{tabular}{cll}
\hline No. & Kriteria & Persentase (\%) \\
\hline 1 & Sangat Baik & $80-100$ \\
2 & Baik & $66-79$ \\
3 & Cukup Baik & $56-65$ \\
4 & Kurang Baik & $40-55$ \\
5 & Tidak Baik & $<39$ \\
\hline
\end{tabular}

\section{B. Pembahasan}

Sesuai dengan tujuan penelitian ini yaitu meningkatkan Literasi matematis siswa kelas IV SD se kota Sintang, mengkaji Perbedaan literasi matematis siswa antara sebelum dan setelah mengerjakan LKS berbasis dongeng dan mengembangkan LKS berbasis dongeng untuk meningkatkan literasi matematis siswa kelas IV sekolah dasar se kota Sintang, oleh karena itu akan dibahas sesuai dengan rumusan penelitian.

Berdasarkan hasil penelitian dan analisis hasil penelitian, diperoleh bahwa secara keseluruhan kemampuan literasi matematis siswa sekolah dasar yang terdapat di kota Sintang masih tergolong rendah dengan rata - rata nilai 42,90. Indikator yang dapat menunjukkan apakah seorang siswa telah mempunyai kemampuan pemecahan masalah, menurut NCTM (2003) adalah: (1) Mampu menerapkan dan mengadaptasi berbagai pendekatan dan strategi untuk menyelesaikan masalah, (2) Menyelesaikan masalah yang muncul di dalam matematika atau di dalam konteks lain yang melibatkan matematika, (3) Membangun pengetahuan matematis yang baru lewat pemecahan masalah, dan (4) Memonitor dan merefleksi pada proses pemecahan masalah matematis. Berdasarkan hasil analisis jawaban siswa, untuk kemampuan pemecahan masalah terdapat $80,95 \%$ atau 51 siswa masih kesulitan dalam memecahkan masalah matematis dengan nilai rata - rata 43,1. Dalam hal ini, siswa mengalami kesulitan dalam menerapkan berbagai pendekatan dan strategi untuk menyelesaikan masalah, membangun pengetahuan atau ide - ide matematis yang baru serta kesulitan dalam mefefleksikan proses pemecahan masalah matematis.

Untuk kemampuan komunikasi matematis, menurut Utari (2006) indikator kemampuan komunikasi matematis adalah: (1) mampu menghubungkan benda nyata, gambar, dan diagram ke dalam ide matematika; (2) mampu menjelaskan ide, situasi dan relasi matematis secara lisan, tulisan, dengan benda nyata, gambar, grafik dan aljabar; (3) mampu menyatakan peristiwa sehari-hari dalam bahasa atau simbol matematika; (4) mampu membuat konjektur, menyusun argumen, merumuskan definisi dan generalisasi. Berdasarkan hasil analisis jawaban siswa, untuk kemampuan komunikasi matematis, terdapat $87,3 \%$ atau 55 siswa mengalami kesulitan dalam hal menghubungkan benda nyata, gambar, dan diagram ke dalam ide matematika; belum mampu menjelaskan ide secara tulisa; belum mampu menyatakan peristiwa sehari-hari dalam bahasa matematika; serta belum mampu membuat konjektur dan menyusun argumen dari masalah matematis.

Indikator penalaran matematis menurut NCTM (2003) adalah mampu membuat dugaan dalam matematika; mampu mengembangkan dan mengevaluasi argumen matematis; mampu memilih dan menggunakan berbagai jenis penalaran dan metode pembuktian. Dari hasil analisis jawaban siswa pada kemampuan penalaran matematis, terdapat rata - rata nilai 41,2. Diketahui bahwa para siswa terdapat $82,54 \%$ atau 52 siswa kesulitan dalam membuat dugaan dalam matematika; kesulitan dalam mengembangkan dan mengevaluasi argumen matematis; belum mampu memilih dan menggunakan berbagai jenis penalaran dan metode pembuktian.

Adapun indikator untuk kemampuan koneksi matematis adalah mampu mengkoneksikan antara ide-ide matematika; mampu mengenali dan menerapkan matematika dalam konteks di luar matematika; mampu menunjukkan keterkaitan ide-ide dalam matematika (NCTM, 2003). Dari hasil analisis jawaban siswa pada kemampuan koneksi matematis, rata - rata nilai yang diperoleh siswa adalah 42,5. Diketahui bahwa 76,19\% atau 48 siswa kesulitan dalam mengkoneksikan dan menunjukan antara ide-ide dalam matematika.

Sedangkan untuk indikator kemampuan representasi matematis adalah mampu menggunakan representasi untuk memodelkan dan menafsirkan fenomena matematika; mampu membuat dan menggunakan representasi untuk mengatur, merekam, dan mengkomunikasikan ide - ide matematis; mampu menerapkan dan terjemahkan di antara representasi matematika untuk memecahkan masalah. Dari hasil analisis jawaban siswa, rata - rata nilai untuk kemampuan ini adalah 47,3. Diketahui bahwa 74,6\% atau 47 siswa kesulitan dalam menggunakan representasi untuk memodelkan matematika, belum mampu membuat dan menggunakan representasi untuk mengkomunikasikan ide ide matematis, serta belum mampu menerapkan dan terjemahkan di antara representasi matematika untuk memecahkan masalah matematika.

Untuk pengembangan LKS dimulai dengan menganalisis kemampuan literasi matematis awal, desain, pengembangan dan evaluasi. Tahap desain yakni mendesain LKS berupa cover, penentuan kompetensi, indikator pencapaian kompetensi dan penyusunan. Tahap pengembangan, memberikan LKS yang telah didesain pada ahli untuk dinilai kelayakannya meliputi: kesesuaian isi, penyajian dan bahasa. Terdapat 4 (empat) validator yang dipilih sesuai dengan bidang keahliannya yang terdiri atas 
satu doktor dalam bidang bahasa dan tiga orang magister pendidikan matematika. Dari penilaian keempat validator diperoleh skor rata - rata 71,03 dengan kategori valid dengan revisi sedang.

Berdasarkan hasil analisis data penelitian diperoleh bahwa setelah siswa mengerjakan lks berbasis dongeng, terjadi peningkatan kemampuan literasi matematis siswa yang awalnya rata - rata hasil tes 42,90 naik menjadi 51,83 . Peningkatan kemampuan literasi matematis siswa dikarenakan beberapa hal, menurut hasil wawancara dengan siswa dan analisis angket respon siswa, bahwa lks berbasis dongeng dikatakan cukup baik dalam membantu siswa meningkatkan kemampuan mereka dalam meliterasi matematika. Hal ini juga tentu karena lks merupakan salah satu sumber belajar yang dapat dikembangkan oleh guru sebagai fasilitator dalam kegiatan pembelajaran. Oleh karenanya LKS menjadi sumber belajar dan media pembelajaran (Widjajanti, 2008). Selain itu dongeng dapat meningkatkan minat membaca pada siswa Sekolah Dasar (SD) kelas IV (Pertiwi, 2011) dan juga dapat meningkatkan kemampuan berkomunikasi untuk pengembangan moral anak-anak usia SD (Ardini, 2012).

\section{IV.SIMPULAN}

Berdasarkan hasil penelitan dan pembahasan, maka dapat disimpulkan bahwa; kemampuan literasi matematis siswa kelas IV SD se-kota Sintang masih rendah dengan nilai rata - rata 42,90 pada semua level kemampuan. Jika dipersentasekan maka terdapat $80,32 \%$ siswa kelas IV SD se-kota Sintang rendah dalam kemampuan literasi matematis. Terdapat perbedaan kemampuan literasi matematis sebelum dan setelah mengerjakan lks berbasis dongeng dengan kenaikan rata - rata hasil tes 8,48 . Lks berbasis dongeng dapat meningkatkan kemampuan literasi matematis siswa se-kota Sintang.

\section{DAFTAR PUSTAKA}

Ardini, P. P. (2012). Pengaruh Dongeng dan Komunikasi Terhadap Perkembangan Moral Anak Usia 7-8 Tahun. Jurnal Pendidikan Anak, 1 (1)

Mullis, I. V., Martin, M. O., Foy, P., \& Arora, A. (2015). TIMSS 2015 International Results In Mathematics. Boston College

NCTM. (2003). Standards for Secondary Mathematics Teacher. United States of America: The National Council of Teachers of Mathematics, Inc.

Pertiwi, A. R. (2011). Peningkatan Minat Membaca Dalam Pembelajaran Bahasa Indonesia Melalui Metode Mendongeng (Story Telling) Pada Siswa Kelas IV SD Negeri Pabelan 02 Kartasura Kabupaten Sukoharjo Tahun Ajaran 2010/2011. (Doctoral dissertation, Universitas Sebelas Maret).

Rosada, U. D. (2016). Memperkuat Karakter Anak Melalui Dongeng Berbasis Media Visual. Jurnal CARE (Children Advisory Research and Education), 4(1), 42-49.

Tjalla, A. (2010). Potret Mutu Pendidikan Indonesia Ditinjau dari Hasil-hasil Studi Internasional. Paper (diterbitkan)

Tjalla, A. (2010). Potret Mutu Pendidikan Indonesia Ditinjau dari Hasil-hasil Studi Internasional. Paper (diterbitkan)

Utari, S. (2006). Berfikir Matematik Tingkat Tinggi: Apa, Mengapa, dan Bagaimana Dikembangkan pada Siswa Sekolah Menengah dan Mahasiswa Calon Guru. Makalah disajikan pada Seminar Pendidikan Matematika di Jurusan Matematika FMIPA Universitas Padjadjaran Tanggal 22 April 2006: tidak diterbitkan.

Widjajanti, E. (2008). Kualitas lembar kerja siswa. In Makalah Seminar Pelatihan penyusunan LKS untuk Guru SMK/MAK pada Kegiatan Pengabdian Kepada Masyarakat Jurusan Pendidikan FMIPA Universitas Negeri Yogyakarta (pp. 2-5) . (2016). Results from PISA 2015 